\title{
A screening test for the detection of methicillin- resistant staphylococci
}

\author{
GILLIAN M. CHURCHER \\ From the Public Health Laboratory and the Department of Pathology, \\ Plymouth General Hospital, Plymouth
}

SYNOPSIS A simple method is described for the detection of methicillin-resistant strains of Staphylococcus aureus by a disc-diffusion test on $5 \% \mathrm{NaCl}$ agar. Information is given about the incidence of these strains in the Plymouth area.

Reports of the isolation of methicillin-resistant strains of coagulase-positive Staphylococcus aureus from patients in hospitals have appeared since 1961, and the estimated incidence of such strains is very variable. Recently in this laboratory several strains of Staph. aureus isolated were noted to give a diminished zone of inhibition with a $10 \mu \mathrm{g}$ methicillin disc on routine sensitivity testing. They had the same or closely related phage-typing patterns, belonging to group III. For this reason, subcultures were inoculated into broth containing $12 \cdot 5 \mu \mathrm{g} / \mathrm{ml}$ methicillin and incubated for 48 hours at $37^{\circ} \mathrm{C}$. All were found to be resistant.

Barber (1964) has shown that methicillin-resistant staphylococci will grow normally in the presence ot methicillin on media containing added $5 \% \mathrm{NaCl}$, which increases the osmotic pressure of the medium and prevents lysis of the organisms. Sutherland (1964) has demonstrated that these staphylococci will grow up to the edge of a $10 \mu \mathrm{g}$ methicillin disc on this medium and suggested that such a test might be suitable for the routine investigation of strains for methicillin sensitivity.

A screening test which utilizes this characteristic of resistant strains is described.

\section{METHODS}

STAPH. AUREUS CULTURES Strains isolated routinely in the laboratory, most of which were selected as described below (see routine sensitivity tests), or because their phage pattern resembled that of resistant strains isolated during the period, and 12 methicillin-resistant strains of varied phage pattern kindly supplied by Dr. K. G. H. Dyke, Colindale were used.

ROUTINE SENSITIVITY TESTS A basal nutrient medium containing casein, yeast, lactate, and glucose with inorganic salts (Marshall and Kelsey, 1960) was modified for

Received for publication 3 July 1967. use as sensitivity agar by the addition of $5 \%$ lysed horse blood. The medium, 3-4 $\mathrm{mm}$ deep, was inoculated by means of a glass rod from a peptone water suspension of the Staph. aureus to give discrete colonies or just confluent growth. Oxoid Multodiscs containing penicillin $(1.5$ units), streptomycin $(10 \mu \mathrm{g})$, tetracycline $(10 \mu \mathrm{g})$, methicillin $(10 \mu \mathrm{g})$, erythromycin $(10 \mu \mathrm{g})$, novobiocin $(5 \mu \mathrm{g})$, and chloramphenicol $(10 \mu \mathrm{g})$ were placed on the plates which were then incubated for 18 hours at $37^{\circ} \mathrm{C}$. Under these conditions sensitive strains of Staph. aureus give zones of inhibition (measured from the disc edge to the margin of inhibited growth) equal to or greater than the following: penicillin $10 \mathrm{~mm}$, streptomycin $4 \mathrm{~mm}$, tetracycline $8 \mathrm{~mm}$, erythromycin $9 \mathrm{~mm}$, novobiocin $7 \mathrm{~mm}$, chloramphenicol $7 \mathrm{~mm}$. Strains which give a smaller zone of inhibition are reported as resistant; in practice such zones are considerably smaller. Strains of Staph. aureus which, on repeated testing, gave a zone of inhibition of $9 \mathrm{~mm}$ or less with the methicillin disc were further tested on $5 \% \mathrm{NaCl}$ agar.

OTHER SENSITIVITY TESTS Representative methicillinresistant strains of different phage-typing patterns were also tested by disc diffusion for sensitivity to cephaloridine $(5 \mu \mathrm{g})$, fusidic acid (10 $\mu \mathrm{g})$, kanamycin (30 $\mu \mathrm{g})$, lincomycin $(2 \mu \mathrm{g})$, and gentamicin $(2 \mu \mathrm{g})$. Neomycin resistance was determined by the method used by Jevons, John, and Parker (1966).

PRODUCTION OF $\beta$ LYSIN AND HYDROLYSIS OF TWEEN 80 These were tested by the method of Jevons et al. (1966).

RESISTANCE TO MERCURY SALTS Green's (1962) modification of Moore's (1960) method was used, with $2 \%$ Oxoid peptone agar.

METHICILLIN DISC SCREEN TEST USING $5 \% \mathrm{NaCl}$ AGAR The medium was of nutrient agar (Hartley's tryptic digest of ox heart) and nutrient agar containing $5 \%$ $\mathrm{NaC1}$. The concentration of agar was $1 \%$.

Discs were of $6 \mathrm{~mm}$ Whatman no. 1 filter paper with $10 \mu \mathrm{g}$ methicillin. These were kept at $4^{\circ} \mathrm{C}$ and checked regularly with the Oxford Staphylococcus (NCTC 6571). Discs not used within one month were discarded. 
Both media were inoculated from a broth culture of the strain under investigation to give a just confluent growth, and a methicillin disc was added. The plates were incubated for 18 hours at $37^{\circ} \mathrm{C}$ aerobically. The zone of inhibition was then measured. Cloxacillin discs, $2 \mu \mathrm{g}$ and $5 \mu \mathrm{g}$, were prepared and used similarly.

METHICILLIN TUBE SCREEN TEST 1 millilitre of nutrient broth (Hartley's tryptic digest of ox heart) containing $12.5 \mu \mathrm{g} / \mathrm{ml}$ methicillin was inoculated with $0.02 \mathrm{ml}$ of an 18-hour broth culture of the staphylococcus. Tubes were incubated at $37^{\circ} \mathrm{C}$ for 48 hours. Strains which grew were considered resistant.

METHICILLIN MINIMUM INHIBITORY CONCENTRATION The method of Jevons, Coe, and Parker (1963) was used. Tubes were examined at 18 and 48 hours. Strains with with a minimum inhibitory concentration (MIC) of 6.25 $\mu \mathrm{g} / \mathrm{ml}$ or greater at 18 hours and which gave a higher value at 48 hours were considered resistant.

POPULATION HOMOGENEITY WITH RESPECT TO METHICILLIN RESISTANCE Two strains, one of phage pattern $53 / 75 / 77 / 83 \mathrm{~A} / 84 / 85$ and one non-typable, were examined on nutrient agar containing methicillin over a range of 0.5 to $250 \mu \mathrm{g} / \mathrm{ml}$ as described by Sutherland and Rolinson (1964).

PHAGE TYPING The method of Blair and Williams (1961) was used. The basic set of typing phages together, with phages 84 and 85 , were supplied by the Cross Infection Reference Laboratory, Colindale.

GROWTH ON $5 \% \mathrm{NaCl}$ AGAR WITH $10 \mu \mathrm{g} / \mathrm{m} 1$ METHICILLIN The method of Dyke, Jevons, and Parker (1966) was used and $0.02 \mathrm{ml}$ of a six hour broth culture of the staphylococcus placed on the surface of the medium and the presence or absence of growth recorded after 18 hours' incubation at $37^{\circ} \mathrm{C}$.

\section{RESULTS}

Over a period of 18 months, from 1 October 1965 to $\overrightarrow{\bar{s}}$ 31 March 1967, strains of Staph. aureus whicho showed a diminished zone of inhibition with the 듬 methicillin disc on routine testing were checked for $\frac{\bar{\sigma}}{7}$ methicillin resistance by the usual methods and on $\widehat{\nabla}$ $5 \% \mathrm{NaCl}$ agar.

Table I summarizes the results of tests on 47 ळ methicillin-resistant strains isolated in this hospital $\vec{O}$ and on 12 known resistant strains. On both sensiti- $\overrightarrow{ }$ vity and nutrient agar they gave a zone of inhibition $\omega_{\sigma}$ of 4 to $9 \mathrm{~mm}$. All grew up to the disc margin on $5 \%$ 응 $\mathrm{NaCl}$ agar.

In Table II the results of testing 21 methicillin- $\overrightarrow{-}$ sensitive strains of similar and dissimilar phage pattern to the resistant strains isolated here are $\vec{\omega}$ shown. While a few gave a zone of 7 to $9 \mathrm{~mm}$ on 0 sensitivity agar most gave one of $10 \mathrm{~mm}$ or more. None grew within $4 \mathrm{~mm}$ of the disc margin on $5 \% \bar{z}$ $\mathrm{NaCl}$ agar. All strains of Staph. aureus with a zone of inhibition of $6 \mathrm{~mm}$ or less on sensitivity agar, and $\frac{\rho}{工}$ most of those with a zone of 7 to $9 \mathrm{~mm}$, were resis- $\vec{\oplus}$ tant. All resistant strains grew up to the methicillin $\underset{\infty}{\varnothing}$ disc on $5 \% \mathrm{NaCl}$ agar on first isolation. On repeat testing, however, a strain occasionally showed a 1 to $3 \mathrm{~mm}$ zone. Colonies were always present in large numbers within the zone under these conditions. Barber (1964) showed that initial anaerobic incubation encouraged normal growth of methi- $\mathbb{Q}$ cillin-resistant strains in the presence of methicillin. $\overline{\overrightarrow{0}}$ Such incubation of $5 \% \mathrm{NaCl}$ agar plates eliminates any tendency of resistant strains to form a small zone of inhibition without reducing the zone of

TABLE I

COMPARISON, OF DIFFERENT TESTS FOR METHICILLIN SENSITIVITY IN METHICILLIN-RESISTANT STRAINS OF STAPH. AUREUS

\begin{tabular}{|c|c|c|c|c|c|c|c|c|}
\hline \multirow[t]{2}{*}{ Source } & \multirow[t]{2}{*}{$\begin{array}{l}\text { Phage Typing } \\
\text { Pattern }\end{array}$} & \multirow{2}{*}{$\begin{array}{l}\text { No. } \\
\text { of } \\
\text { Strains } \\
\text { Tested }\end{array}$} & \multirow{2}{*}{$\begin{array}{l}\text { Methicillin } \\
\text { Inhibition } \\
\text { Zone on } \\
\text { Sensitivity } \\
\text { and Nutrient } \\
\text { Agar }\end{array}$} & \multirow{2}{*}{$\begin{array}{l}\text { Methicillin } \\
\text { Inhibition } \\
\text { Zone on } \\
5 \% \mathrm{NaCl} \\
\text { Agar }\end{array}$} & \multirow{2}{*}{$\begin{array}{l}\text { Growth on } \\
\text { Methicillin } \\
\text { Salt } \\
\text { Agar }\end{array}$} & \multirow{2}{*}{$\begin{array}{l}\text { Methicillin } \\
\text { Tube } \\
\text { Screen }\end{array}$} & \multicolumn{2}{|c|}{$\begin{array}{l}\text { Methicillin MIC } \\
(\mu \mathrm{g} / \mathrm{ml})\end{array}$} \\
\hline & & & & & & & 18 Hours & 48 Hours \\
\hline Plymouth & $\begin{array}{l}53 / 75 / 77 / 83 \mathrm{~A} / 84 / 85 \\
6 / 7 / 47 / 53 / 54 / 77 / 84 / 85 \\
53 / 75 / 83 \mathrm{~A} \\
75 / 77 / 84 / 85+ \\
53 / 85 \\
\text { N.T. } \\
29 / 52 / 52 \mathrm{~A} / 53 / 75 / 77 / 83 \mathrm{~A} \\
53 / 75 / 77 / 84 / 85 \\
80 / 53 / 75 / 77 / 84 / 85+ \\
53 / 75 / 77 / 84 / 85+ \\
53 / 75 / 77 / 84+\end{array}$ & $\begin{array}{r}23 \\
3 \\
1 \\
1 \\
1 \\
1 \\
1 \\
5 \\
1 \\
6 \\
4\end{array}$ & $4-9 \mathrm{~mm}$ & $0 \mathrm{~mm}$ & $\begin{array}{l}+ \\
+ \\
+ \\
+ \\
+ \\
+ \\
+ \\
+ \\
+ \\
+\end{array}$ & $\begin{array}{l}+ \\
+ \\
+ \\
+ \\
+ \\
+ \\
+ \\
+ \\
+ \\
+ \\
+\end{array}$ & $\begin{array}{l}6 \cdot 25-12 \cdot 5 \\
12 \cdot 5 \\
6 \cdot 25 \\
12 \cdot 5 \\
12 \cdot 5 \\
12 \cdot 5 \\
12 \cdot 5 \\
6 \cdot 25-12 \cdot 5 \\
12 \cdot 5 \\
6 \cdot 25 \\
6 \cdot 25-12 \cdot 5\end{array}$ & $\begin{array}{l}50->100 \\
>100 \\
>100 \\
>100 \\
>100 \\
100 \\
>100 \\
>100 \\
>100 \\
>100 \\
50-100\end{array}$ \\
\hline $\begin{array}{l}\text { Colindale } \\
+=\text { grow } \\
\mathrm{N} T .=\mathrm{N}\end{array}$ & Various & 12 & & & + & + & $12 \cdot 5-25$ & $50->100$ \\
\hline
\end{tabular}


TABLE II

COMPARISON OF DIFFERENT TESTS FOR METHICILLIN SENSITIVITY IN METHICILLIN-SENSITIVE STRAINS OF STAPH. AUREUS

\begin{tabular}{|c|c|c|c|c|c|c|c|}
\hline \multirow[t]{2}{*}{$\begin{array}{l}\text { Phage Typing } \\
\text { Pattern }\end{array}$} & \multirow{2}{*}{$\begin{array}{l}\text { No. } \\
\text { of } \\
\text { Strains } \\
\text { Tested }\end{array}$} & \multirow{2}{*}{$\begin{array}{l}\text { Methicillin } \\
\text { Inhibition } \\
\text { Zone on } \\
\text { Sensitivity } \\
\text { and Nutrient } \\
\text { Agar }\end{array}$} & \multirow{2}{*}{$\begin{array}{l}\text { Methicillin } \\
\text { Inhibition } \\
\text { Zone on } \\
5 \% \mathrm{NaCl} \\
\text { Agar }\end{array}$} & \multirow{2}{*}{$\begin{array}{l}\text { Growth on } \\
\text { Methicillin } \\
\text { Salt } \\
\text { Agar }\end{array}$} & \multirow{2}{*}{$\begin{array}{l}\text { Methicillin } \\
\text { Tube } \\
\text { Screen }\end{array}$} & \multicolumn{2}{|c|}{$\begin{array}{l}\text { Methicillin MIC } \\
(\mu \mathrm{g} / \mathrm{ml})\end{array}$} \\
\hline & & & & & & 18 Hours & 48 Hours \\
\hline $53 / 75 / 77 / 83 A / 84 / 85$ & 2 & & & - & - & $3 \cdot 12,6 \cdot 25$ & $6 \cdot 25$ \\
\hline $53 / 75 / 77 / 83 A$ & 2 & & & - & - & $3 \cdot 12$ & $6 \cdot 25$ \\
\hline $47 / 53 / 54 / 75 / 83 \mathrm{~A} / 85$ & 1 & & & - & - & $6 \cdot 25$ & $6 \cdot 25$ \\
\hline $7 / 47 / 53 / 54 / 75 / 77 / 83 \mathrm{~A} / 84 / 85$ & 1 & & & 一 & - & $3 \cdot 12$ & $6 \cdot 25$ \\
\hline $6 / 7 / 47 / 53 / 54 / 75 / 83 \mathrm{~A}$ & 1 & & & - & - & $3 \cdot 12$ & $3 \cdot 12$ \\
\hline $53 / 77 / 83 \mathrm{~A} / 84$ & 2 & & & - & - & $3 \cdot 12$ & $6 \cdot 25$ \\
\hline $7 / 47 / 53 / 54 / 77$ & $\mathbf{1}$ & & & 一 & - & $6 \cdot 25$ & $6 \cdot 25$ \\
\hline $77 / 84 / 85$ & 2 & & & - & 一 & $3 \cdot 12,6 \cdot 25$ & $6 \cdot 25$ \\
\hline $53 / 77 / 83 \mathrm{~A}$ & 1 & $7-12 \mathrm{~mm}$ & 4-10 mm & - & - & $3 \cdot 12$ & $6 \cdot 25$ \\
\hline $53 / 83 \mathrm{~A}$ & 1 & & & - & - & $3 \cdot 12$ & $6 \cdot 25$ \\
\hline $77 / 85$ & 1 & & & - & - & $3 \cdot 12$ & $3 \cdot 12$ \\
\hline $83 \mathrm{~A}$ & $\overline{1}$ & & & - & - & $3 \cdot 12$ & $6 \cdot 25$ \\
\hline 80 & 1 & & & - & - & $3 \cdot 12$ & $3 \cdot 12$ \\
\hline $52 \mathrm{~A} / 80 / 81$ & 1 & & & - & - & $3 \cdot 12$ & $3 \cdot 12$ \\
\hline $52 \mathrm{~A} / 79 / 80$ & 1 & & & - & - & $3 \cdot 12$ & $3 \cdot 12$ \\
\hline $71+$ & 1 & & & - & - & $3 \cdot 12$ & $3 \cdot 12$ \\
\hline Oxford staphylococcus & 1 & $11-13 \mathrm{~mm}$ & $11-13 \mathrm{~mm}$ & 一 & - & $\leqslant 1.56$ & $\leqslant 1.56$ \\
\hline
\end{tabular}

sensitive strains. Anaerobic incubation as a routine, however, appears unnecessary.

When 2 and $5 \mu \mathrm{g}$ cloxacillin discs were tested on $5 \% \mathrm{NaCl}$ agar neither disc gave as clear a distinction between resistant and sensitive strains as did methicillin. Since all strains resistant to methicillin are also resistant to cloxacillin, methicillin discs only were used.

With the use of $5 \% \mathrm{NaCl}$ agar confirmation of methicillin resistance is available within 48 hours. Swabs may, in fact, be plated directly onto $5 \% \mathrm{NaCl}$ agar and a $10 \mu \mathrm{g}$ methicillin disc added. Provided the number of staphylococci present is such that near confluent growth is obtained in the region of the discs, results are available within 18 hours. This is of particular value when cross infection is thought to be occurring in the ward with a methicillin-resistant strain.It is not advisable to use media containing $5 \%$ $\mathrm{NaCl}$ to test strains of Staph. aureus for sensitivity to other antibiotics; not only does false resistance to streptomycin occur (Berkman, Henry, and Housewright, 1947; Green and Waksman, 1948) but novobiocin-resistant strains show a zone of inhibition and might be reported as sensitive.

Since October 1965, 61 patients are known to have been infected with seven distinct methicillinresistant strains of Staph. aureus; 59 of these patients were infected in hospital. With two exceptions, no patient had been treated with methicillin or cloxacillin previously and neither of these two had been treated within a month of isolation of the resistant strain. The strains isolated resemble resistant strains previously described in that they are members of phage group III and consist of a heterogeneous population with respect to methicillin resistance (two strains tested). All were mercury resistant and resistant to penicillin, streptomycin, tetracycline, and cephaloridine. ${ }^{1} \mathrm{~A}$ few were also resistant to erythromycin and chloramphenicol. They were all sensitive to neomycin, fusidicacid, lincomycin, kanamycin, and gentamicin. Two strains produced $\beta$ lysin and two split Tween 80 . One of them, of phage pattern $53 / 75 / 77 / 83 \mathrm{~A} / 84 / 85$, caused an outbreak of wound, respiratory tract, and urinary tract infection in a male surgical ward in which 17 patients were known to have been infected over a period of six months. None of the infections was severe, but there was considerable delay in wound healing. Cross infection with a strain of similar phage pattern also occurred in an orthopaedic ward in a different hospital. This strain was isolated from the nose, perineum, and bedsores of several elderly patients screened regularly for staphylococcal carriage.

\section{DISCUSSION}

Naturally occurring methicillin-resistant strains of Staph. aureus are strong penicillinase producers and also intrinsically resistant to methicillin. All strains investigated appear heterogeneous with respect to resistance, consisting of a majority population with a comparatively slight increase in resistance and a minority population with a considerable increase in resistance (Knox, 1961; Knox and Smith, 1961;

\footnotetext{
${ }^{1} \mathrm{On} 5 \% \mathrm{NaCl}$ agar a reduced zone of inhibition is also shown by these strains with cephaloridine discs.
} 
Sutherland and Rolinson, 1964). This unusual form of resistance gives rise to difficulty in the detection of resistant strains by the usual disc diffusion methods (Parker and Jevons, 1964; Sutherland, 1964; Eriksen, 1964; Courtieu, Guillermet, Longeray, Maka, and Chabbert, 1964) and some strains may not have been recognized. Some strains may also have been missed by reporting only those with a minimum inhibitory concentration of at least $12.5 \mu \mathrm{g} / \mathrm{ml}$ at 18 hours as resistant.

In this laboratory, by testing on $5 \% \mathrm{NaCl}$ agar all strains of Staph. aureus which showed a reduced zone of inhibition on sensitivity agar, it has been possible to divide stappylococci into methicillin'resistant' and 'sensitive' groups. The test is simple and rapid, an advantage over the $12.5 \mu \mathrm{g} / \mathrm{ml}$ tube test which requires 48 hours' incubation, and therefore of particular value in a routine bacteriological laboratory. Dyke et al. (1966) showed that the distinction between methicillin-resistant and methicillin-sensitive strains of Staph. aureus is not clear cut and that some of the methicillin-sensitive strains of Staph. aureus resistant to multiple antibiotics are a little more resistant (MIC $6.25 \mu \mathrm{g} / \mathrm{ml}$ at 18 hours) to methicillin than those resistant only to penicillin or sensitive to all antibiotics. Work here with a few such strains tends to suggest this (Table III): most of the strains resistant to several antibiotics had an MIC of $6.25 \mu \mathrm{g} / \mathrm{ml}$ at 48 hours, whereas fully sensitive strains tended to have a lower MIC. These strains of slightly increased resistance were not detected reliably by the methicillin disc screen although, as can be seen from Table IV, they tended to give a smaller zone of inhibition than fully sensitive strains.

Therapeutic levels above the MIC of methicillinresistant strains are said to be obtainable in the blood stream with cloxacillin and it is important to know how patients infected with methicillin-resistant
TABLE IV

CORRELATION OF METHICILLIN ZONE OF INHIBITION WITH ANTIBIOTIC SENSITIVITY

\begin{tabular}{|c|c|c|c|}
\hline \multirow{2}{*}{$\begin{array}{l}\text { Antibiotic } \\
\text { Sensitivity }\end{array}$} & \multirow{2}{*}{$\begin{array}{l}\text { No. of } \\
\text { Strains } \\
\text { Tested }\end{array}$} & \multicolumn{2}{|c|}{ Disc Screen Zone of Inhibition (Range in $\mathrm{mm}$ ) } \\
\hline & & Nutrient Agar & $5 \% \mathrm{NaCl}$ Agar \\
\hline $\begin{array}{l}\text { Penicillin } \\
\text { sensitive or } \\
\text { resistant to } \\
\text { penicillin only }\end{array}$ & 20 & $8-12$ & $7-11$ \\
\hline $\begin{array}{l}\text { Resistant to } \\
\text { multiple } \\
\text { antibiotics } \\
\text { Methicillin } \\
\text { sensitive }\end{array}$ & 20 & $5-10$ & $4-10$ \\
\hline $\begin{array}{l}\text { Resistant to } \\
\text { multiple } \\
\text { antibiotics } \\
\text { Methicillin } \\
\text { resistant }\end{array}$ & 20 & 4-9 & 0 \\
\hline
\end{tabular}

strains respond to treatment with methicillin or the isoxazolyl penicillins. There are few published reports. Chabbert, Baudens, Acar, and Gerbaud (1965) have shown that patients with resistant strains do not generally respond as well as those with sensitive strains and suggested that kanamycin or streptomycin might be used in combination. Recently the opportunity to study the response in two patients occurred here:

One, a woman of 60 , had an infected neck wound (following the incision and drainage of a tuberculous cervical abscess) which failed to heal. She was given $500 \mathrm{mg}$ of cloxacillin orally q.d.s. for five days when treatment had to be stopped because of suspected penicillin allergy. This failed to clear the wound or nose of the strain. Fusidic acid achieved this and the wound healed.

The second patient, a woman of 64 , had an infected amputation stump. Treatment with oral cloxacillin (500 mg q.d.s. for seven days) caused temporary disappearance of the staphylococcus from the nose and amputation stump, but the strain reappeared later.

TABLE III

CORRELATION OF METHICILLIN SENSITIVITY WITH SENSITIVITY TO OTHER ANTIBIOTICS

\begin{tabular}{|c|c|c|c|c|c|c|c|c|c|}
\hline \multirow{2}{*}{$\begin{array}{l}\text { Antibiotic } \\
\text { Sensitivity }\end{array}$} & \multirow{2}{*}{$\begin{array}{l}\text { No. of } \\
\text { Strains } \\
\text { Tested }\end{array}$} & \multicolumn{7}{|c|}{ Methicillin MIC $(\mu \mathrm{g} / \mathrm{ml})$} & \multirow{2}{*}{$\begin{array}{l}\text { Time of } \\
\text { - Reading } \\
(h r)\end{array}$} \\
\hline & & $\leqslant 1.56$ & $3 \cdot 12$ & $6 \cdot 25$ & $12 \cdot 5$ & 25 & 50 & $\geqslant 100$ & \\
\hline $\begin{array}{l}\text { Penicillin } \\
\text { sensitive or } \\
\text { resistant to } \\
\text { penicillin only }\end{array}$ & 20 & $\begin{array}{l}6 \\
2\end{array}$ & $\begin{array}{l}13 \\
10\end{array}$ & $\begin{array}{l}1 \\
8\end{array}$ & & & & & $\begin{array}{l}18 \\
48\end{array}$ \\
\hline $\begin{array}{l}\text { Resistant to } \\
\text { multiple } \\
\text { antibiotics }\end{array}$ & 20 & & 15 & 4 & & & & & 18 \\
\hline $\begin{array}{l}\text { Methicillin } \\
\text { sensitive }\end{array}$ & & & 4 & 16 & & & & & 48 \\
\hline $\begin{array}{l}\text { Resistant to } \\
\text { multiple } \\
\text { antibiotics }\end{array}$ & 20 & & & & 13 & 4 & & & 18 \\
\hline $\begin{array}{l}\text { Methicillin } \\
\text { resistant }\end{array}$ & & & & & & 1 & 5 & 14 & 48 \\
\hline
\end{tabular}


Strains of Staph. aureus isolated from both patients after treatment were tested for sensitivity and no increase in resistance was found. In the outbreak on the surgical ward previously mentioned patients were treated with cloxacillin together with other antibiotics. This did not appear to select organisms of higher resistance either, as strains isolated at the end of the outbreak had similar MICs to those isolated at the beginning.

The reported incidence of methicillin-resistance is varied. Parker and Jevons (1964) tested more than 40,000 cultures sent for phage typing from a large number of hospitals since 1960 . They showed that, up to the middle of 1962, the percentage of resistant cultures fluctuated between 0.06 and 0.29 . Since then it has risen to and remained at about 0.6 . Colley, McNicol, and Bracken (1965), in a general hospital between September 1962 and 1964, reported an incidence of $4.8 \%$. Chabbert et al. (1965), in their study of a highly selected group of staphylococcal cultures from Paris hospitals, gave figures for 1962 of $17 \%$ (127 strains) and for 1963 of $19 \%$ (134 strains). In the Lyons area Courtieu et al. (1964) found 31 of 216 strains isolated resistant, an incidence of $14.3 \%$ of staphylococci considered to form a representative sample from the area. While selection of the strains examined probably accounts for most of this variation in incidence, variation may also be due to difficulty in the interpretation of disc sensitivity tests.

In this laboratory all strains of Staph. aureus isolated are phage typed. Most of these come from infected hospital patients but a proportion (about $20 \%$ ) are from patients, mainly geriatric, screened regularly for carriage. Strains from patients outside hospital form an insignificant number. During the 18-month period stated, 3,793 staphylococci were phage typed and $123(3.2 \%)$ of these were methicillin-resistant. If strains resistant to penicillin and at least one other antibiotic are considered only, the incidence is $7.6 \%$. Since methicillin-resistant strains are also resistant to several other antibiotics and tend to cause outbreaks of infection, reports of incidence, as Barber (1962) emphasized, can be misleading. A high figure may be largely a reflection of the extent of cross infection. A truer assessment here of the incidence of methicillin resistance, obtained by excluding all strains known to have been acquired as the result of cross infection, is $4 \cdot 2 \%$. Again, if those from clinically infected patients only are considered, the incidence is about $6.9 \%$.

Methicillin-resistant strains of Staph. aureus, first recognized in this hospital in October 1965, have now become endemic. The $5 \% \mathrm{NaCl}$ agar test should prove useful in defining the extent and significance of this resistance.

I wish to thank Dr C. H. Jellard and Dr M. T. Parker for their interest and helpful criticism in preparation of the paper, Dr M. Patricia Jevons for confirming the methicillin resistance of three strains early in the course of this study, the physician and surgeons concerned for their helpful cooperation, and Mr. L. T. S. Lowther who phage typed the cultures of Staph. aureus.

\section{ADDENDUM}

In the month (April 1967) following the period reviewed an additional 18 patients have been infected with methicillin-resistant strains.

\section{REFERENCES}

Barber, M. (1962). In Resistance of Bacteria to the Penicillins, edited by A. V. S. de Reuck and M. P. Cameron (Ciba Foundation Study Group, no. 13), p. 89. Churchill, London.

(1964). J. gen. Microbiol., 35, 183.

Berkman, S., Henry, R. J., and Housewright, R. D. (1947). J. Bact., 53, 567.

Blair, J. E., and Williams, R. E. O. (1961). Bull. Wld. Hlth, Org., 24, 771 .

Chabbert, Y. A., Baudens, J. G., Acar, J. F., and Gerbaud, G. R. (1965). Rev. franc. Etud. clin. biol., 10, 495.

Colley, E. W., McNicol, M. W., and Bracken, P. M. (1965). Lancet, 1,595 .

Courtieu, A. L., Guillermet, F. N., Longeray, C., Maka, G., and Chabbert, Y. A. (1964). Ann. Inst. Pasteur, 107, 691.

Dyke, K. G. H., Jevons, M. P., and Parker, M. T. (1966). Lancet, 1, 835.

Eriksen, K. R. (1964). Proc. XIV scand. Congr. Path. Microbiol., Oslo, 233.

Green, S. M. (1962). J. clin. Path., 15, 249.

Green, S. R., and Waksman, S. A. (1948). Proc. Soc. exp. Biol. (N.Y.), 67, 281.

Jevons, M. P., Coe, A. W., and Parker, M. T. (1963). Lancet, 1, 904.

—, John, M., and Parker, M. T. (1966). J. clin. Path., 19, 305.

Knox, R. (1961). Brit. med. J., 1, 126.

, and Smith, J. T. (1961). Lancet, 2, 520.

Marshall, J. H., and Kelsey, J. C. (1960). J. Hyg. (Lond.), 58, 367.

Moore, B. (1960). Lancet, 2, 453.

Parker, M. T., and Jevons, M. P. (1964). Postgrad. med. J., 40, suppl., 170.

Sutherland, R. (1964). Ibid., 40, suppl., 187.

—, and Rolinson, G. N. (1964). J. Bact., 87, 887. 